\title{
QUALITY OF SERVICE AND CONTROL GOVERNOR'S RECOMMENDATION UTILIZATION OF NORTHERN BANDUNG AREA IN THE OFFICE OF CAPITAL INVESMENT AND ONE STOP INTEGRATED SERVICE THE PROVINCE OF WEST JAVA
}

\author{
${ }^{1}$ Irvan Niko Firmansyah, ${ }^{2}$ Soleh Suryadi, ${ }^{3}$ Eddy Jusuf Sp \\ ${ }^{1}$ Postgraduate Student of Pasundan University \\ ${ }^{23}$ Pasundan University \\ irvanniko84@gmail.com
}

\begin{abstract}
Government is an organization that has full responsibility on the improvement of public service quality. Consequently service becomes the prior task of organization's officials as civil and public servants. There are 197 licenses and non-licenses public services. Therefore, it is important to maintain and improve service quality continuously. Meanwhile, the existing service quality hasn't shown significant result. It can be viewed from public complaints on the publication process of governor's recommendation of land use in North Bandung Region, yet there were a lot of field control that its implementation irrelevant with the recommendation. Complaints, indictments and inappropriateness recommendation in the field need to be minimized in order to optimize service quality and control conducted by West Java Provincial Government on the publication process of governor's recommendation of land use in North Bandung Region. Accordingly, researcher would like to conduct further study on how Service Quality and Control of Governor's Recommendation of Land Use in North Bandung Region performed by West Java Provincial Government, as well as to study strategies that can be applied in order to improve service quality. This research applied qualitative study using snow ball technique to objects of study, i.e. public service administrator; public service customer; public service observer, primarily those who are involved in the legalization of governor's recommendation of land use in North Bandung Region. The data were obtained through interview and deep analysis using triangulation observers. The research of the study reveals that the inconsistency of service quality is influenced by 10 dimensions, i.e. tangibles, reliability, responsiveness, courtesy, credibility, security, access, communication and understanding consumer. On the other hand, environment control, risk assessment, control activities, information and communication, yet monitoring control are determinant factors in controlling governor's recommendation of land use in North Bandung Region. It is done by applying strategy that implement technology, innovation and operation approach. From the research, it is found new dimensions, they are: institutional coordination, supervision, collaboration, prosecution and policy diversification through GSMALL Collaboration Model (Government, Society, Media, Academic, and Law Enforcement).
\end{abstract}

Keyword: service quality 


\section{INTRODUCTION}

Government is an organization that has full responsibility on public service for public needs in a broad sense. Public service that is represented as governor's recommendation of land use in North Bandung Region basically is one form of administrative service. This kind of service is done extensively by the government. Hence it is the obligatory task of the government to do so. The effort to improve service quality should be done by applying one-stop-service centre as stated in Indonesian Government Regulation no 96, 2012 (PP No. 96 Tahun 2012). This regulation has already applied by West Java Provincial Government. It is stated in service procedure to which all licenses' process of land use in North Bandung Region should be done within 14 days. By doing so, hopefully the service control can be done perfectly and optimally for the society. With this standard procedure and limitation, hopefully service quality and control can be improved perfectly and significantly, moreover it can work professionally, responsively, innovatively and friendly in accordance with its function and duty. However, the reality in the field showed that the process doesn't work optimally. It can be recognized to which there are a lot of complaints about it. It can be seen from the data below (2016-2017):

Table 1.1

Data Recapitulation of Governor's Recommendation of Land Use in North Bandung Region 2016 to 2017

\begin{tabular}{|l|l|l|l|l|l|}
\hline \multirow{2}{*}{ No. } & \multirow{2}{*}{ Month } & \multicolumn{2}{|l|}{ Application Status } & Complaints & $\begin{array}{l}\text { Total of } \\
\text { Application }\end{array}$ \\
\cline { 3 - 6 } & & Approved & Disapproved & & 1 \\
\hline 1 & January & 40 & - & 4 & 40 \\
\hline 2 & February & 28 & - & 1 & 28 \\
\hline 3 & March & 53 & - & 7 & 53 \\
\hline 4 & April & 61 & 36 & 4 & 61 \\
\hline 5 & May & 82 & 31 & 5 & 113 \\
\hline 6 & June & 110 & 35 & 7 & 145 \\
\hline 7 & July & 50 & 54 & 7 & 104 \\
\hline 8 & August & 97 & 35 & & 132 \\
\hline
\end{tabular}

IJSOC ( $) 2020$ 


\begin{tabular}{|l|l|l|l|l|l|}
\hline 9 & September & 73 & 13 & 3 & 86 \\
\hline 10 & October & 69 & 32 & 12 & 101 \\
\hline 11 & November & 90 & 21 & 5 & 111 \\
\hline 12 & December & 78 & 12 & 2 & 90 \\
\hline 13 & Adv ocacy Compl aints & 63 & 63 \\
\hline & Total & $\mathbf{8 3 1}$ & $\mathbf{2 6 9}$ & $\mathbf{1 2 1}$ & $\mathbf{1 1 0 0}$ \\
\hline
\end{tabular}

Source: Report of Complaints and Advocacy in Control Division in West Java Province 2016 to 2017

From table 1.1, it indicates that from 2016-2017 there are 1100 licenses' application in North Bandung Region, of the total applications there were 831 or $75,55 \%$ approved, 269 or 24,45 rejected. Meanwhile, there are 121 applicants who show dissatisfaction toward service receiver, it's about $10,6 \%$ of the total applicants. These complaints should be minimized in order to optimize service quality of West Java Provincial Government regarding the governor's recommendation of land use in North Bandung Region. Some testimonies on customers' complaints were obtained from claimed report data and advocacy of control division of West Java Province 2016 -2017, as shown below:

1. Amazing, the licenses application process in West Java Province was awful, since November 2016 my application wasn't responded seriously. Until now the result is still unclear. Help! please pay attention to all the process that I had been going through all this time. (Mrs Henry Hanindia's complaint)

2. Mistype in the document, first floor should be second floor. (Mr Hardi Setiawan's complaint)

3. On the applicants' register form of governor's recommendation of land use in North Bandung Region, it is stated that register date was January 30 ${ }^{\text {th' }} 2017$ and the due date was March 13 th, 2017 , unfortunately until now (April 17 th 2017), the process hasn't finished yet and when I try to contact Investment Coordinating Board of West Java Provincial Government but there was no response at all. The public administrator performance was very bad. It doesn't reflect a strong governmental basic principle. (Mr Taufan Wizard Lufthansa's complaint).

In the meantime, based on the control activity in the location, it indicates that there are 211 recommendations' application or 25,39\% of total 831 applications that are approved, however the reality does not reflect the same 
thing. The application cannot fulfil the licenses' requirements. If it is categorized, then it can be said that there were 5 influential factors affect the process but the main factor is the developing plan in the area exceeded the coefficient level of constructed area. The lack of coordination among Provincial, Municipal and Regency Government causing Building Construction Permit are minus recommendation from Provincial Government. The building exceeded the construction height and floor coefficient level, inappropriate buildings' construction and converted land function. From the number of customers' complaints and dissatisfaction, as well as service quality control that is still not optimum, it is indicated that service quality and control that is done by West Java Provincial Government hasn't performed optimally in fulfilling customers' expectations and demands.

Apart from that, there is also environmental impact because the misusing of governor's recommendation in North Bandung Region e.g. flood and landslide that often occurred in Bandung. Developer often made some environmental licenses' violation that causing ecosystem imbalance, primarily concerning water reservoir. It is marked by a lot of people's well that were dry slowly, moreover there was some usable water reservoir that was missing. Due to the fact that so many people's demands and complaints on service quality, administrator should consider it as a challenge and opportunity in doing their main duty and function to improve the service. The effort of understanding customers' needs, expectations and satisfaction is stated by Zeithaml et.al, namely by identifying 10 dimensions: tangibles, reliability, responsiveness, competence, courtesy, credibility, security, access, communication, understanding customer. Thus, the control dimension that is applied in this research refer to internal control dimension formulated by COSO (2013:4) in Internal Control-Integrated Framework (ICIF). The dimensions are: 1) Control Environment 2) Risk Assessment 3) Control Activity 4) Communication and Information 5) Internal Monitoring Control.

Considering the phenomenon, researcher thoughtfully thinks that those dimensions have been already applied but don't give a real impact as to improve service quality and control better than before. It can be seen from preliminary analysis and observation on the existing documents explained previously. Therefore, the researcher interested to study it again comprehensively on how strategy and control are done by West Java Provincial Government to improve service quality and control, especially in publishing governor's recommendation 
in North Bandung region. This research examined problems that happened 2016 - 2017. Hence, the title of this research is: "Service Quality and Control of Governor's Recommendation of Land Use in North Bandung Region, West Java Province “

\section{Statement of the Problem}

1. How is service quality of Governor's Recommendation in North Bandung Region performed by West Java Provincial Government?

2. How is service control of Governor's Recommendation in North Bandung Region performed by West Java Provincial Government?

3. What strategy that can be applied in examining Service Quality and Control of Governor's Recommendation in North Bandung Region performed by West Java Provincial Government?

\section{The purpose of the Research}

1. To analyse service quality of Governor's Recommendation in North Bandung Region performed by West Java Provincial Government?

2. To analyse service control of Governor's Recommendation in North Bandung Region performed by West Java Provincial Government?

3. To formulate strategy that is derived from research Service Quality and Control of Governor's Recommendation in North Bandung Region performed by West Java Provincial Government?

\section{Literature Review}

Literature review is conducted to describe Public Administrative Theory as grand theory, one of which is stated by Atmosudirjo (1990:28); Public Management Theory as middle range theory put forward by Moenir (2002), Whilst, the description of this theory is a general comprehensive view of concepts and previous researches that set as a basis theoretically and is used to support research findings based on analysis of a few variables in this research. Some results of the previous researches are:

1. Leif Sanner's research, June 5, 2008, The Impact of Employee Empowerment on Service Quality and Customer Satisfaction in Service Organizations ( $A$ Case Study of Lansforsakringar Bank AB, Bachelor Thesis in Business Administration, Department: School of Sustainable Development of Society and Technology. School: Malardalen University, Vasteras. 
2. Mohamad Haidar Mustaghfiri, Priyanto Susiloadi's research, 2017, Jurnal Wacana Publik, Vol 1 No.2,. Kualitas Pelayanan Penerbitan Izin Mendirikan Bangunan di Dinas Penanaman Modal dan Pelayanan Terpadu Satu Pintu Kota Surakarta.

\section{Public Administration Concept}

Atmosudirjo (1990:28) stated that administration has 3 meanings, they are:

1. Administration is a leading system of an organization of employment or company. It is the main Function of Administrator that is management.

2. Administration is an information system that controls certain situation, circumstances and organization. The point of administration is informative control system of management.

3. Administration is a cooperation process between 2 people or more in such a way that they can share the same goals. The point is decision making.

Based on Atmosuirjo, those 3 meanings have some functions, namely: Government Administration as Government's function is to organize and manage government's affairs; Government administration as an Organization that control Governmental management and Government administration as a management process of varied tasks and affairs is done systematically, properly, methodically and technically. The view is also in accordance with Denhardt \& Denhardt's view (2013:1) In a sense that:

Public administration is concerned with the management of public programs. Public administrators work at all levels of government, both at home and abroad, and they manage nonprofit organizations, associations, and interest groups of all kinds. The substantive fields within which public managers work range across the varied interests of government and public affairs, from defense and national security to social welfare and environmental quality, from the design and construction of roads and bridges to the exploration of space, and from taxation and financial administration to human resources management. Though public administration varies tremendously in its scope and substance, those who work in public organizations share certain commitments. Among these, none is more important than a commitment to public service.

This statement is closely related by public program management in which public administration works at any governmental level, whether at domestic and 
foreign level as well as non-profit organizations, associations and interest groups of all kinds. Though public administration varied tremendously in scope and substance but those who work in public organization share certain commitment on it. The same commitment should also be undertaken by government's institutions interchangeably among executive, legislative and judicial level.

\section{Public Management Concept and Public Service}

State management is often called public management of government affairs. Based on a new concept and function of public management. Denhardt \& Denhardt (2007:57) pointed that:

The new public management addresses the relationship between government and citizens, not just a practical concern, but from a distinct theoretical position. Earlier in this chapter we examined in detail the ideal concept of citizenship as being active, involved, and public spirited. We also pointed out the alternative legal definition of citizenship - a view we find to be based not only on legalism but also on self-interest. This theoretical viewpoint so clearly underlies the way in which the new public management views the relationship between those in government and those served or regulated by government that is worthwhile to elaborate the theoretical notion of citizen as consumer. This view is largely derived from the so-called economic theory of democracy, a theory that explains political behavior in terms of economic competition. Political parties, for example, are seen as competing for votes just as corporations are seen as competing for profits. Citizens, in turn, are seen as consumer for whose votes the parties compete. The citizen/consumers make decisions based on their efforts to maximize their own utilities, casting their votes for one or the other party, or simply turning away form politics and seeking great utilities by spending their time and energy elsewhere (dagger 1997, 105).

According to Denhardt \& Denhardt, the language of customers service has become the center of a new public management. The goal of national service, for example is to provide customer service that is similar to business (Gore 1993;44). There are no long queue anymore, information shortage, unfriendly employee because the government has set the service standard and take necessary effort to fulfill those standards. The same approach and language are also applied in district and state level, to which the government and their institutions are trying to renew themselves as operational support system that is generated by consumer. In another country, the same approach is also applied, in fact, in many 
cases government is more reactive than the labour union itself. According to Denhardt \& Denhardt, there are some elements that determine service quality in public sector i.e : 1) Convenience 2) Security 3) Reliability 4) Personal Attention 5) Problem solving approach 6) Justice 7) Fiscal Responsibility 8) Citizen's caretaker.

H.A.S Moenir (2002:16 -17) in his book entitled Public Management Service inIndonesia defined service as:

Activity is a process of using mind, brain, five senses all parts of the body without any help from anyone to get something that is desired both in form of materials and services. The process of fulfilling needs through somebody else's activity that is done directly is called service.

Service is an essential government's tool to provide people's needs. Through this activity, people can give evaluation on government's performance. In relevance with this in Zeithaml, Valarie A (et.al) book entitled Delivering Quality Services (1990) to which it discussed about how people's perception and expectation toward the service that they were received, both in form of materials and services. Basically, there are 3 main components that determines the quality of public services. They are described below: 
Inter Personal

Component

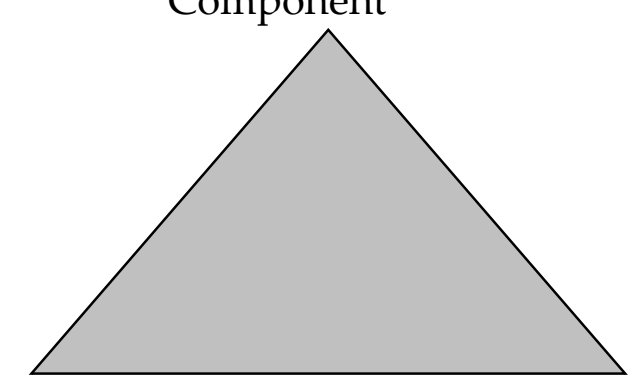

Process and Environment

Professional \&Technical

Component

Component

Source: Warsito Utomo, 1997

Picture 2.1

The Triangle of Balance in Service Quality

\section{Public Service Quality}

Quality is literally defined as an overall features and characteristics of a service product that affects the ability to satisfy needs. Quality refers to a dynamic condition that correlates with product, service, people, process and environment that meet or exceed expectations. Those expectations, basically depends on how suppliers can give satisfaction to their customers. Based on service insight, there are 2 elements involved in the service, they are servant and customer. Servant is a person who gives service to the customers, meanwhile customer concept hasn't publicly used as an alternate word for society in terms of service. Zeitahml et.al identified 10 criteria or public dimensions, and then labelled them as: tangible, reliability, responsiveness, competency, courtesy, credibility, security, access, communication and understanding customer. The model that is widely used as a reference to determine service quality is SERVQUAL. It is connected 2 dimensions, so called: evaluation of customer dimension as well as provider dimension, in other word it lies within the perceived service quality that is performed by provider at managerial and front line service. The measurement of this model may create a gap between customers' expectations and perceptions of service delivered by service provider. Zeitahml identified 5 gaps causing service dissatisfaction, they are:

1. Gap between consumer expectation and management perception; 
2.Gap between management perception and service-quality specification;

3. Gap between service-quality specifications and service delivery;

4. Gap between service delivery and external communications;

5. Gap between perceived service and expected service

If those gaps are combined it will become Conceptual Model of Service Quality that is stated by Zeithaml et.al (1990:131) as follow:

\section{Strategy in Improving Public Service}

The framework of public service as public policy is also interpreted as an instrument that is able to prevent corruption and misuse of power, to improve professionalism and officials' performance. To reach the goal, it is necessary to design an adaptive and effective strategy toward the dynamics of environment and technology development, yet applicable to the customer itself. Ellitan et.al (2008:23) stated that there are 3 main strategies that are applied in an organization in order to enhance public services, they are: 1) Technology strategy 2) Innovation strategy 3) Operation strategy.

\section{Internal Control Design}

Dimension or internal control components that are used in this research refer to internal control analysis that describe in COSO (2013:4) in the form of Internal Control Integrated Framework (ICIF). Those references have similar dimensions, namely: 1) environment control 2) risk assessment 3) control activity 4) information and communication 5) internal control supervision. 


\section{Framework}

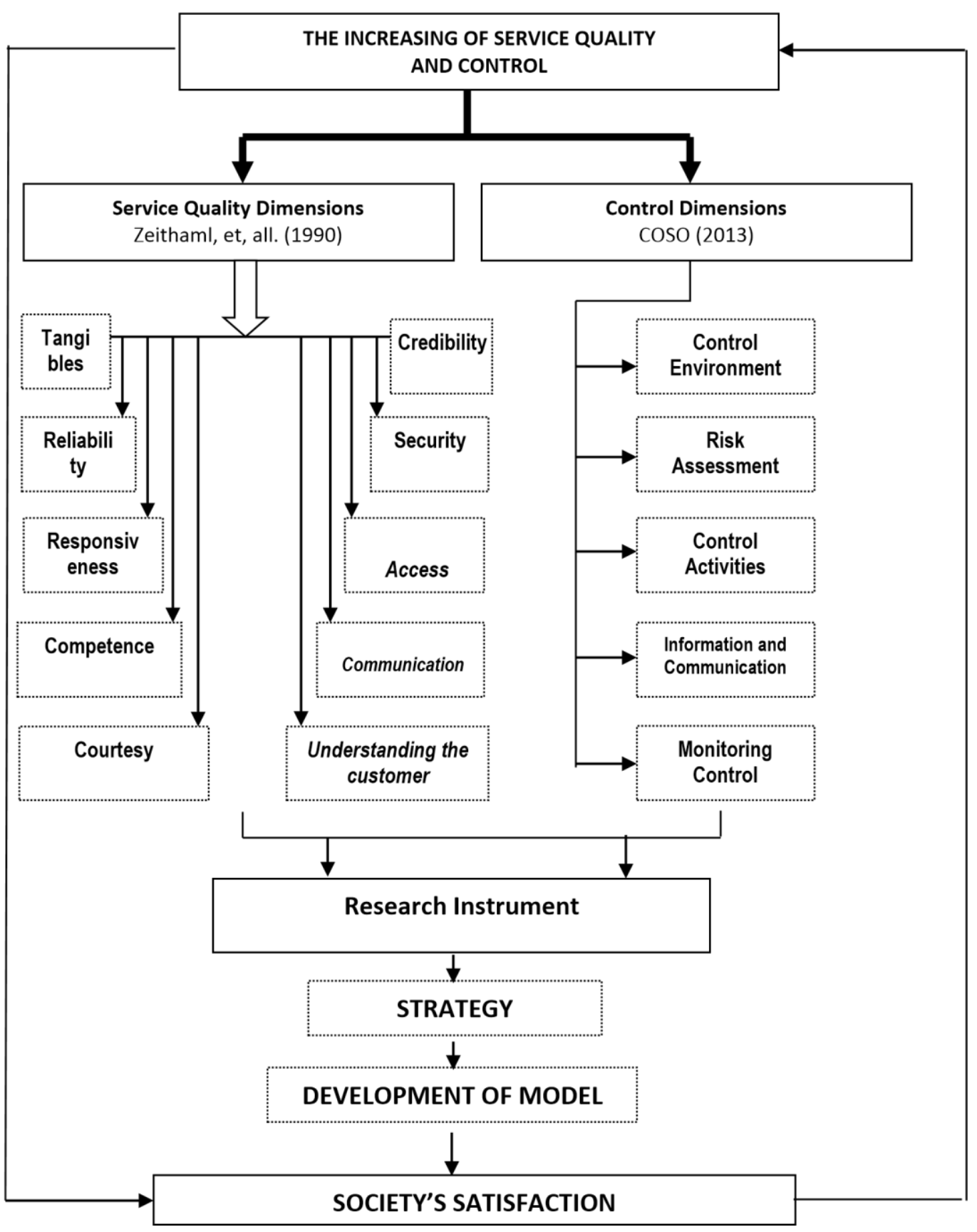

Picture

Framework 
The propositions namely: tangibles, reliability, responsiveness, competence, courtesy, credibility, security, access, communication and understanding the customer. Those are the main dimensions that determine service quality, on the other hand, control environment, risk assessment, control procedure, information and communication also monitoring are the main dimensions that determine the governor's recommendation of land use in North Bandung Region.

\section{RESEARCH METHODOLOGY}

The method of this research is qualitative paradigm or qualitative research approach. This sampling techniques and object of the research derived from primary and secondary sources, literature study, observation and also interview. The informant for this research were public service provider, public service receiver, and public services observers, primarily those who are involved in providing the governor's recommendation of land use in North Bandung Region, West Java Province. The representativeness and classification of data sources were integrated through triangulation approach. The interviews were conducted based on open-ended questionnaires which were formulated from SERVQUAL Theory from Zeithaml et.al (1990: 20).

\section{DISCUSSION AND RESULT OF THE RESEARCH}

This research has presented the services quality that performed by West Java Government due to the governor's recommendation of land use in North Bandung Region. It is based on ten dimensions stated by Zeithml (1990) and also control based on 5 dimensions stated by COSO (2013). According to the overall data, the West Java Government has been successful in improving customer's satisfaction but indeed there are still some dimensions and service quality that need to be improved. Some aspects regarding tangible dimension is the use of information and communication technology that hasn't covered all of service process, therefore it can distract the coordination process between leading sector and the lack of personnel. Reliability dimension is unit network that hasn't been integrated well under the same roof, coordination among divisions hasn't worked efficiently and work procedure with technical teams that need to be optimized. Responsiveness dimension is not so fast in handling consumer's complaints. Competence dimension is there are still personnel who work in different work 
field; Competence dimension is there isn't any standardized work ethic and rules in SOP; Credibility is the lack of controlling and monitoring supervision internally and externally in the field after the governor's recommendation has been approved; Security dimension namely there is inadequate assurance of Law enforcement to the license's violation and also no assurance in service duration; Access dimension is the availability of back office personnel who is doing administrative service is still inappropriate with the needs; meanwhile Communication dimension namely the performance of monitoring supervision and socialization is still not optimum.

The analysis showed that service quality regarding the integrated system that covered all aspects of service administration start from application process, document verification and field survey, technical analysis, recommendation publication and also supervision haven't been optimum. Based on onestopintegrated service-centre context the performance of other local institutions (vertically and horizontally) is also contributed to the service quality that is given. It is because of the one-stop-service system that is applied hasn't been integrated to all local institutions under a new organization system, on the contrary, it is still in the form of coordination among institutions. Therefore, the assessment of service quality of land use license $\mathrm{n}$ North Bandung region should be elaborated with the system, management and also the coordination among institutions. Referring to this the West Java Government should build synergism with technical teams of the Spatial Planning and Development Agency in West Java Province in local institutions in the city and regency and also Law Enforcement Institutions as well as Regional Regulation. Apart from that, the supervision aspect is also crucial factor in order to give assurance of Law Enforcement in licensing field, assurance to the society that they will receive service quality in accordance with the existing standard operating procedure and also to minimize the potential violation and misapply the recommendation or the license that has already given. Referring to that explanations, the researcher found that there is new dimension to measure the service quality of governor's recommendation of land use in North Bandung region namely institutions' coordination and supervision.

Research finding based on the theory stated by the researcher revealed that there is a new dimension in Zeithmal theory et all namely institutions' coordination. It is important element that can enhancing the government onestopservice centre in West Java Province, its indicators are: solid and compact work 
mechanism in one-stop-service centre, to clarify work collaboration management and work division. Institutions' coordination is one element that should be added into the research of licensing in one-stop-service centre, it can develop and strengthen the reliability, responsiveness and access dimension. The quality of institutions' coordination regarding the licensing service can give an overview on how the service can be performed based on regulation and the existing standard that have been set. Referring to the explanation, it can be stated that institutions' coordination dimension is one of the most crucial factors in evaluating and enhancing government's service quality.

Another finding of the research shows that there is contribution of supervision factor in enhancing service quality of one-stop-service centre, especially concerning the governor's recommendation of land use in North Bandung region. The supervision must be conducted optimally as it is done internally and externally within the institution. Supervision dimension is developed from credibility, courtesy and security dimension. Supervision dimension is an integrated part of one-stop-service centre, supervision is a joint responsibility between licensing institution and technical regional unit. The result of this research shows that supervision towards the implementation of governor's recommendation of land use $\mathrm{n}$ North Bandung region has become one of the parameter in measuring the achievement of service quality. Direct and continuing evaluations should be done by West Java Government internally and externally, it begins from application process, front office service, document verification, field survey, technical analysis until recommendation publication. This research also found that supervision in environment control of North Bandung region at provincial, municipal and regency level in West Java province influence people's perception towards government's service quality, especially the license of land use in North Bandung region. The administrative licensing service is an integral part of application service process until supervision toward license that has already been given. Referring to that, the environment control supervision is suitable with the regulation and it correlates with public's perception toward indiscriminative law enforcement.

Based on the data and strategy analysis put forward previously, it is necessary to redesign service system and to control governor's recommendation of land use in North Bandung region. In the continuing improvement framework, it is needed a model of licensing service that is more innovative focusing on the improvement that is appropriate with this research finding and it is to enhance 
government of West Java province performance as leading sector, to clear out sectionalism and bureaucratic among Regional Working Unit (OPD), to facilitate and empowering stakeholder of non-governmental institutions to take part in the process of implementation and supervision, and also to give legal security in the process of land use in North Bandung Region. According to that improvement focus, it is needed a model that can facilitate synergy among each stakeholders who is concerned in improving the licensing service in West Java. The model that is derived from this research namely collaboration model of Government, Society, Media, Academic and Law Enforcement (GSMAL). The stakeholder changes correlate with the context of this research concerning the governor's recommendation of land use and also research finding that shows that service improvement and supervision in West Java need a synergy among Government, Society, Media, Academic and Law Enforcement. Collaboration and synergy among stakeholder can be viewed like this:

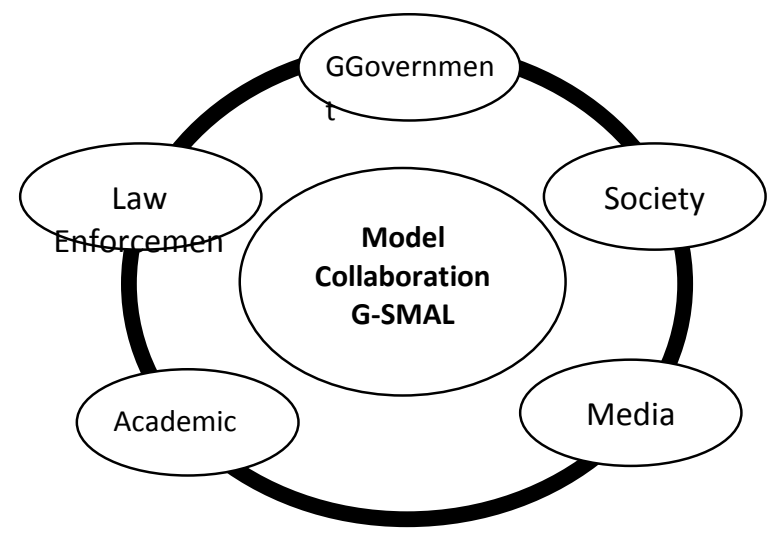

Picture :

Collaboration Model GSMAL in improving service quality and Management Control of Governor's Recommendation of Land Use in North Bandung Region, West Java Province (Source: data processed by researcher, 2019)

Each unit in this GSMAL model has a role and function that contribute in the improving of service quality and license management control as per data presented below:

1. Academic. Through their skill and researches, academic can put forward new concept regarding the innovation in control and operational system. 
2. Government, as a regulator they should think out variety of law product and innovative policy that can enhance the service quality of one-stopservice centre. With the government authority in giving license, they should be able to formulate it in order to simplify licensing process as well as to improve quality of management control based on healthy and clean governance principle.

3. Media. The role of the media is very important in educational and socialization process for stakeholder, through information distribution of government regulations programs. With its independency, media takes part as government's partner in controlling service quality. Therefore it can thrust service's accountability and transparency.

4. Society. In this case, society through group formation, organization or community is also participated in supervising the implementation of land use. They can give information concerning indication of violation in the field, a valuable input in improving service quality \& management control.

5. Law enforcement. With its authority, they can do preventive act and prosecution to protect and give legal security to public.

The collaboration is compiled based on basic principle of innovative model which consists of institutional aspect, service orientation and public governance stakeholder. The basic principle of this innovative model is presented below:

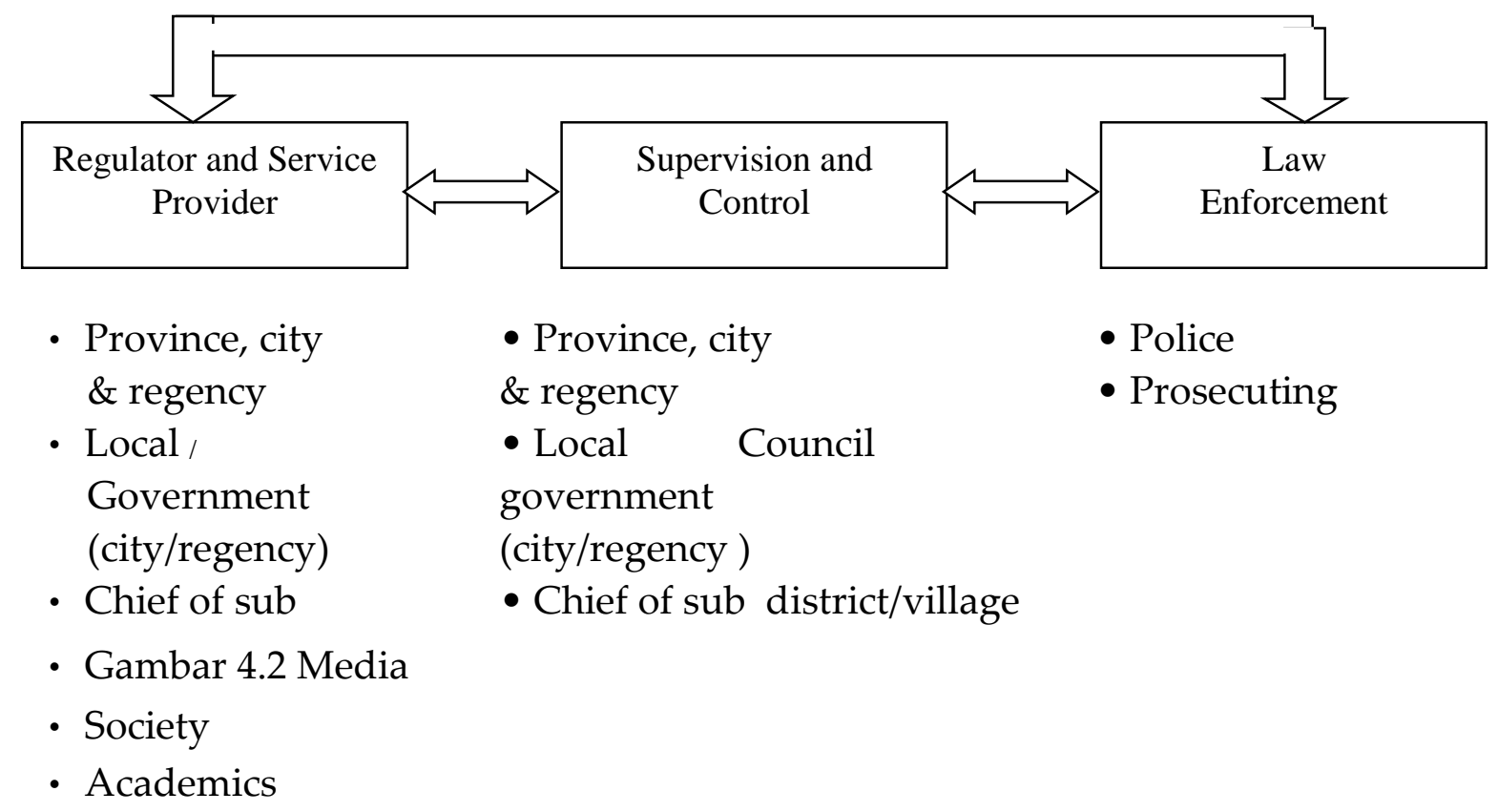

IJSOC @ 2020 
International Journal of Science and Society, Vol 2, Issue 1, March 2020

- Public order enforcers (Satpol PP)

\section{Picture :}

The Model of Service and Controlling Governor's Recommendation of Land Use in North Bandung Region

(Source: processed by researcher, 2019) 
Furthermore, the scheme of correlation between research findings and research theory described below:

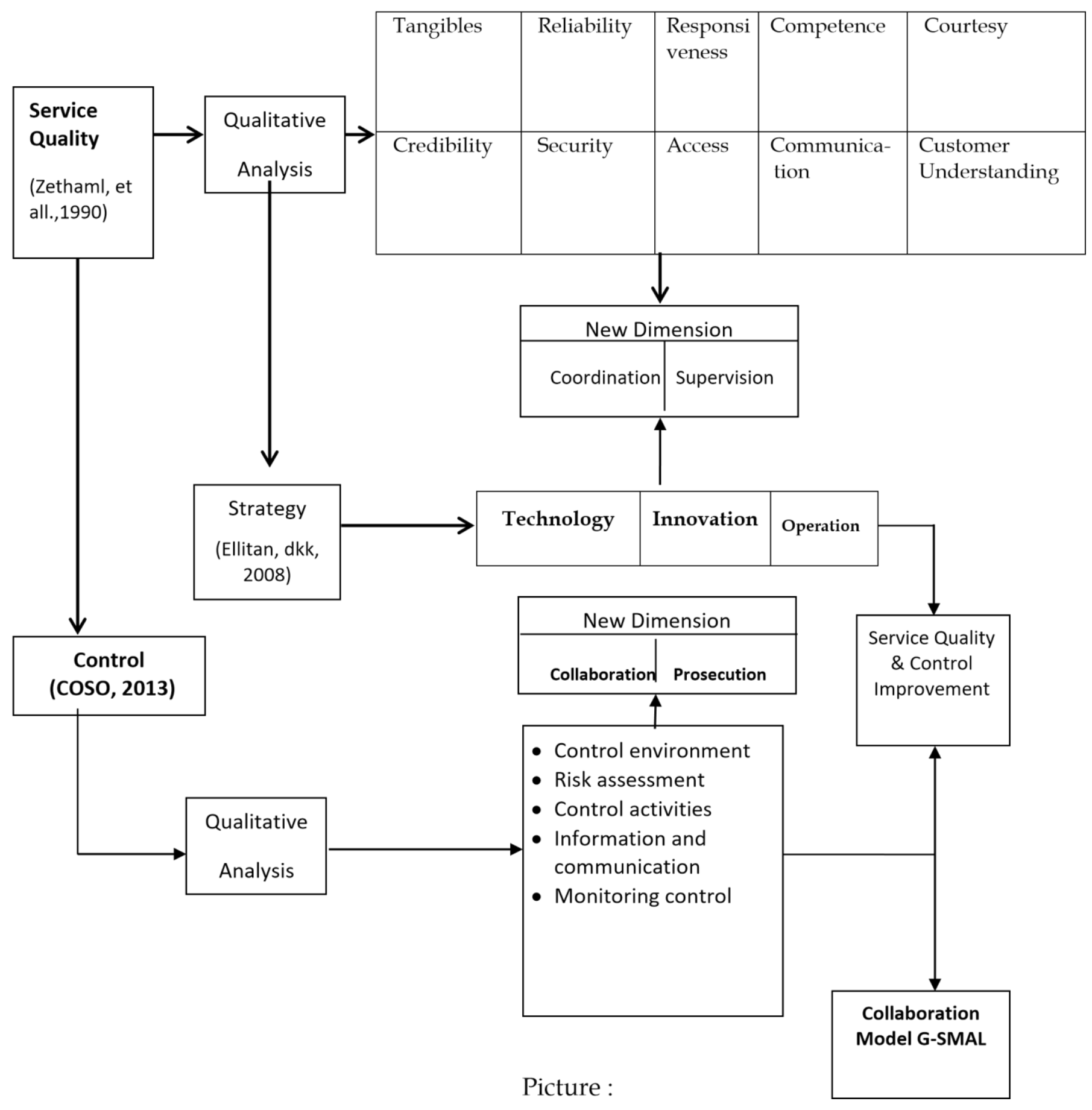


Correlation between research findings and applied theory towards service quality and governor's recommendation control of land use in North Bandungregion, West Java Province

\section{CONCLUSION}

Based on the analysis, it is found that service quality of the integrated system which covered all administrative service aspects including applying process, documents verification, field survey, technical analysis, recommendation publishing as well as supervision aren't optimum. Based on the context of licenses' one-stop-service, the performance of other regional working unit (both vertically \& horizontally) also contribute to the service quality that is given. It is because of the systems hasn't already integrated all of the regional working unit into a new organization, on the other hand, it still appear in a form of coordination among institutions. According to that, assessment of service quality of governor's recommendation of land use in North Bandung region should be connected with the elaboration through system, management and also coordination procedure among institutions. In this case how the One Stop Integrated Service Department builds synergy with the technical team from Regional Road Offices and Spatial Planning Agency of West java Province, local government in municipal and regency level, law enforcer institutions and regional regulations. Apart from that, supervision is also an important aspect in giving legal security referring to governor's recommendation, assurance to the society that they will receive service quality that fulfil the standard operating procedure and also to minimize the appearance of misuse recommendation or legal violations of the license that has already given.

Referring to that, researcher found that there was a new dimension in measuring service quality of governor's recommendation of land use in North Bandung Region, those are institutions' coordination and supervision.

Based on that, it is also needed to improve the control system of governor's recommendation of land use, not only in the dimension of effective control environment but also risk assessment, control activity, information and communication, as well as supervision control.

a. To create an effective control environment, West Java Provincial government hasn't conducted strategic evaluation independently on organization 
structure that is correlated with the strategy and dynamics environmental changes.

b. Not all identification results and risk assessment analysis are communicated to all employees and the technical team of Regional Working Unit, therefore it creates different perception and potential risk that should be able to be coped with.

c. The control activity has been working regularly and continuously. In the process, it is necessary to optimize the use of information and technology, to give decentralization authority not only to technical team of Regional Working Unit but also other technical units from local institutions tin order to legalize the documents that have been applied by the society.

d. Local institutions has had mechanism and communications path between each related divisions that manage all process of licenses, recommendation of land use in North Bandung region.

e. Local institutions have done continuous monitoring through audit, supervision and other steps proceeded by the chief of divisions and their employees informally regarding task implementation.

Regarding that, researcher indicated that there is a new dimension in measuring service quality of governor's recommendation of land use in North Bandung Region, they are collaboration and prosecution. Meanwhile, the strategies that can be applied on service quality and control of governor's recommendation of land use in North Bandung Region are:

a. Technology strategy is conducted by developing one-stop service centre; building an integrated licensing data; connecting complaints data base with the existing information system.

b. Innovation strategy is conducted by forming task force unit due to supervise governor's recommendation of land use in North Bandung Region.

c. Operation strategy is conducted by doing continuous evaluation on standard operating procedure of service based on internal and external development.

\section{Recommendation}

1. The implementation of GSMAL Collaboration Model with stakeholder elements, namely: Government, Society, Media, Academic, and Law Enforcement. 
2. Giving a decentralization of authority widely to the technical teams, using information and communication technology, and documents' based electronic/digitalization in the whole process of application settlement.

3. It is necessary to apply other methods, such as mystery shopping or ghost shopper that can be used as comparative data that is taken from the society.

4. It is necessary to synchronize the vision between provincial government and municipal/regency government referring to governor's recommendation of land use in North Bandung Region.

5. It is necessary to do innovation of one-stop service method by forming an integrated task force unit in North Bandung.

6. Further research can apply mix methods of qualitative and quantitative method.

7. Further research should add concept and theory about organization system that influences service quality vision and implementation into research operation. 


\section{REFERENCES}

1. Atmosudirdjo, Prajudi. 1990. Dasar-Dasar Administrasi Negara, Jakarta : Ghalia Indonesia.

2. Commitee of Sponsoring Organizations of the Tradeway Commission (COSO). 2013. Internal Control-Integrated Framework. North Carolina : COSO.

3. Denhardt, Janet V. and Denhardt, Robert B, 2007, The New Public Service. : M.E. Sharpe, Inc.

4. 2013, Public Administration: an action orientation, seventh edition: wadsworth : USA

5. Ellitan, Lena dan Anatan, Lina. 2008. Manajemen Strategi Operasi : Teori dan Riset di Indonesia. Bandung : Alfabeta.

6. Moenir. H.A.S. 1992,2001,2002. Manajemen Pelayanan Umum di Indonesia. Jakarta: Bumi Akssara.

7. Mohamad Haidar Mustaghfiri, Priyanto Susiloadi, 2017, Jurnal Wacana Publik, Vol 1

8. No.2,. Kualitas Pelayanan Penerbitan Izin Mendirikan Bangunan di Dinas Penanaman Modal dan Pelayanan Terpadu Satu Pintu Kota Surakarta

9. Pemerintah Nomor 96 Tahun 2012 tentang Pelaksanaan Undang-Undang Nomor 25 Tahun 2009 tentang Pelayanan Publik

10. Sanner, Lief 2008. The impact of employee empowerment on service quality and custumer satisfaction in service organizations ( $A$ Case study of lansforsakringar Bank $A B$ ) Bachelor Thesis in Business Administration. Department School of Sustainabel Developmentof Society and Technology. School : Malardalen University, Vasteras.

11. Utomo, Warsito. 1997. Peranan dan Strategi Peningkatan Asli Daerah dalam Pelaksanaan Otonomi Daerah,. Jogjakarta : dalam jurnal Ilmu Sosial dan Ilmu Politik, volume 1.

12. Zeithaml. Valarie, A, Parasuraman, A and Berry. Leonard. 1990. Delivering Quality Service : Balancing Customer perceptions and Expectations. The Free Press : Adivision of Macmillan. Inc. 